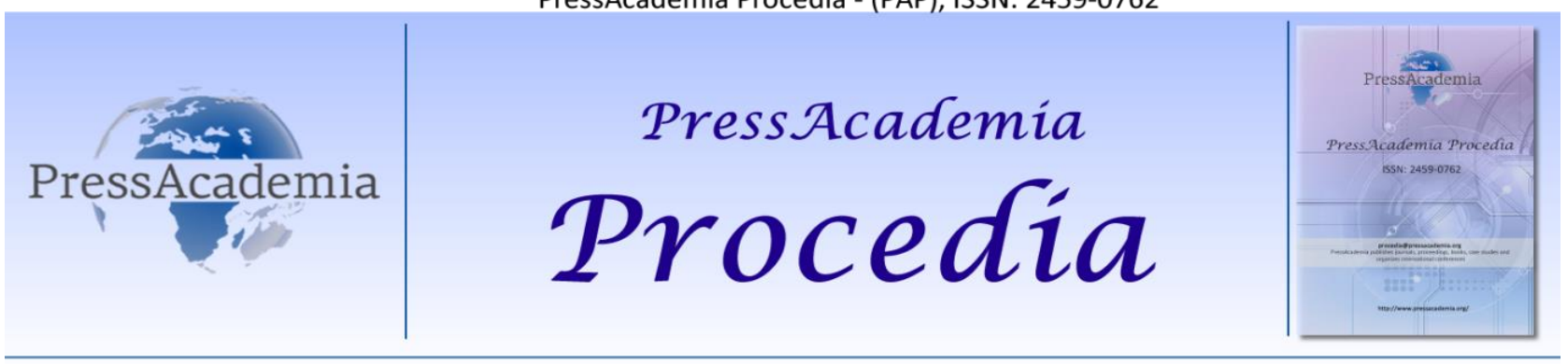

2nd World Conference on Technology, Innovation and Entrepreneurship

May 12-14, 2017, Istanbul, Turkey. Edited by Sefer Şener

\title{
E-HEALTH APPLICATIONS in TURKEY
}

\author{
DOI: 10.17261/Pressacademia.2017.679 \\ PAP-WCTIE-V.4-2017(55)-p.422-432
}

\section{Demokaan Demirel}

Niğde Ömer Halisdemir Üniversitesi ,iiBß Kamu Yönetimi Bölümü, Niğde, Turkey. demokaand@gmail.com

\begin{abstract}
Today's states are living the stage of information society after agriculture and industrial society level. The concepts such as speed, quality, efficiency and productivity have gained importance in the information society. The most important competitive tool in the information society is the acquisition of information and sharing among the institutions. The most important contribution of the information society to public administration reforms is the e-government, which provides advantages in terms of time and labour costs. E-government practices strengthen communication between citizens and administrative institutions. E-government is accelerating mutual communication between public institutions and increases communication possibilities. It makes public administrators accountable directly to the public. It prevents administrative corruption. It increases citizen participation in administrative processes and political practices in a democratic manner. The ehealth, which refers to the e-government's practices in the health sector, ensures that the services provided to all stakeholders are delivered quickly and easily in the field of health. Turkey is still in its first phase in e-health applications. Since the announcement of the health transformation program in 2003, many e-health projects have been developed and put into practice. This study aims to explain the concepts of information society and e-government, to examine and evaluate the e-health applications in Turkey. From a methodological point of view, the study discusses the e-health projects in Turkey in a methodological way starting from the literature on e-government theory. It demonstrates the contribution of e-health projects in Turkey's e-transformation process.
\end{abstract}

Keywords: Information Society, Information Technology, e-government, e-health, Turkey. JEL Codes: J110, JI18.

\section{INTRODUCTION}

The most important agenda item in public administration reforms since the 1990s is the effectiveness of the state. The effectiveness of the state necessitates an increase in administrative performance. Administrative performance is directly related to the use of scarce resources allocated to public services. Qualified presentation of public services will reduce public expenses. With a decrease in public expenditure, the state will invest more in the public sector and economic rationality will be provided in resource use. When public services are offered equally to the citizens, the satisfaction of the citizens is of great importance. Meeting the expectations and demands of the citizens affects the level of trust in the state. In this context, information and communication technologies are being utilized by the government to implement fast, efficieny, effectiveness and low cost public policies. These technologies eliminate the differences between time and space.

E-government is one of the administrative reform instruments aimed at increasing citizen satisfaction in public services. With egovernment applications bureaucratic procedures can be done easily and cheaper. One of the most important indicators of the information society is the increase in the use of information and communication technologies. With e-government policies, any public service can be offered to the citizen in an electronic form. Health services are public services that citizens use mostly as a semi-public service. The effective presentation of health services is a requirement of becoming a social state in the constitutional framework. In this regard, e-health applications are being spread so that public institutions can exchange 
information among themselves and between institutions; make it easier for health personnel and citizens to access information about the health sector, and process and store national health data records for citizens. E-health applications aim to provide modern and quality health services based on knowledge and information systems. In this study, informatics politics in Turkey in the field of health services are considered from a theoretical point of view based on the literature reviews.

In the study, the concepts of information society and e-government are mentioned first. In the second part of the study, the policies carried out by the Ministry of Health are explained within the scope of starting e-health applications in Turkey. The Ministry of Health has undertaken a number of projects to provide transforming the information society and has acted as an active political leader in e-health applications. The scope of e-health projects in the study is also revealed. This study aims to analyze the position of Turkey in the field of e-health applications by evaluating the basic qualities of the e-health projects carried out by the Ministry of Health. The widespread use of e-health applications by citizens, apart from the policies of the Ministry of Health at the central level, will increase the chances of success of these projects.

\section{INFORMATION SOCIETY and E-GOVERNMENT CONCEPTS}

From past to present, humanity history has passed three important stages. These stages were described by Toffler as agricultural, industrial revolution and information revolution. Toffler notes that technical innovations have shaped the world by three waves. The first wave is the agriculture revolution that started in $8000 \mathrm{BC}$ with the invention of primitive agricultural machines and wheat farming. The second wave is the technical developments that started discovering with the steam power in 1650 years and continued with the internal combustion engine and electricity. These technological developments have led to the Industrial Revolution. The beginning of the third wave dates back to the 1950s. In this period, the number of white-collar workers is more than the number of blue-collar workers. The peak point of the development of industrialization and the service sector in the third wave, the information revolution has emerged.

The process of transition from the industrial society to the information society has been accelerated by the development of technology and the use of information in all areas of life. The basic production factor in the economy in the information society is knowledge. The vast majority of people work in sectors based on knowledge. Constantly large amounts of information are produced in each area, and these informations can be easily transmitted with the aid of information technology. People can easily access information without time and space constraints (Güleş and Özata, 2005: 29-30). For this reason, one of the most emphasized points in post-modern management theories is the provision of organizational communication based on healthy information exchange. The best way to differentiate organizations from their competitors is to be able to make use of the information in a perfect way. The way of collecting, managing and using information determines to win and lose in the organizational competition (Gates and Hamingway, 1999: 23).

The organizational use of information technology changes the information processing operations vertically and horizontally. Some researchers have pointed out that information technology has strengthened the central decision-making process in a hierarchical structure upwards and downwards. Others state that information technology recognizes the ability to control the information processing process for lower-level employees effectively and efficiently and decentralizes the decision making process. (Moon, 2014: 8). The features distinguishing information technologies from other technologies are as follows (Izci, 2001: 41; Moon, 2014: 9):

$\checkmark \quad$ The collection of information: Information technology helps to provide, store, and protect information. It permits the taking of the printed copy, if necessary, to make corrections or addings. It ensures that every transaction made is recorded. The adoption of information technology by public administration is a tool for improving organizational performance and productivity.

$\checkmark \quad$ The storage of information: Information technologies accumulate and store information. It turns the information into numerical units and stores it for use.

$\checkmark \quad$ The processing of information: Data entered in the computer is processed into information.

$\checkmark \quad$ The display of information: Information technologies transmit and display informations electronically.

$\checkmark \quad$ The control of bureaucratic transactions: Information technology enables the determination and correction of deviations in bureaucratic transaction performance. The relationship between information technology and organizational performance focuses highly on internal management functions such as decision making, effective communication, and superior operational performance. 
E-government is a term used to emphasize the application of information and communication technologies in administrative systems and processes. New models for policy formation, alternative forms of citizenship, changes in forms of power and partnership, new solutions for economic development are of interest to the e-government. It also adopts alternative approaches to increasing the participation of citizens in political processes. It looks favorably on different models of authority and partnerships. It produces new solutions related to economic development (Asgarkhani, 2005: 468).

The aims of the e-government are as follows (Asgarkhani, 2005: 469):

$\checkmark \quad$ To provide the on-line presentation of public services and the automation of administrative systems.

$\checkmark$ To ensure widespread adoption of network-based technology.

$\checkmark \quad$ Reducing costs by moving administrative processes to internet environments.

$\checkmark$ To prevent corruption in public administration.

$\checkmark$ To encourage economic growth through information-communication technologies.

$\checkmark \quad$ To increase citizen participation to enable political accountability and to improve democracy.

The fact that the citizen and/or customer in e-government have paid more attention to the perceived qualitative value than the cost of a service must be considered in the implementation of services and costs. The e-government increases cooperation among public institutions by reducing public expenditures and attaches great importance to citizen satisfaction. It consists of phases such as increasing of different informations, online support, citizens' support and the foundations of operational facilities (Affisco and Soliman, 2006: 20).

The services offered in e-government practice are (Homburg, 2008: 755-756):

1- Information Services: These services focus on the disclosure of government regulations, policy reports, other official documents and brochures.

2- Communication Services: These are concerned with making a complaint to administration or asking questions to civil servants and politicians about the implementation of certain rules and programs.

3- Transaction-Based Services: It is about digital tax cuts, permits, licenses and subscriptions. It emphasizes the management of specific demands and applications for staff rights and responsibilities, electronic data entries.

4- Participation Services: It is broader than electronic voting. Electronic forums and virtual communities offer political participating opportunities to citizens, pressure groups and third parties for evaluating policy programmes such as rebuilding a railway, a shopping center, and a political program, the environment regulation.

5- Data Transfer Services: It enables basic and standard information sharing and exchange between public institutions, public and private sector organizations.

The administrative approach to information technologies in public administration and e-government studies is trying to put various administrative values into life through applications of information technologies. This approach requires information technologies to take the place of human power in organizations (Moon, 2014: 7-8). In services and costs offered through egovernment, citizen and/or customer focuses on qualitative value perceived more than cost of the public service (Affisco and Soliman, 2006: 20).

In the public sector, the effectiveness of e-technologies and network-assisted solutions can be influenced by some social and cultural factors (Asgarkhani, 2005: 474):

$\checkmark \quad$ Information Security: Technological progress allows public institutions to aggregate and preserve data about individuals and organizations. This, however, can create a problem for the management of information for such institutions.

$\checkmark \quad$ Impact on Occupations and Workplaces: Despite technical progress, the idea that computers will take the place of human power is not on the agenda as it used to be. Instead, people are focused on the health risks associated with continuous computer-based working.

$\checkmark \quad$ Impact on Individual Rights and Private Life: Companies and administrative agencies collect, store, and make accessible data about individuals and their private lives. Access to such large-scale information may pose a danger, particularly in terms of politically corrupted public institutions.

$\checkmark \quad$ Potential Impact on Society: Despite some economic benefits of ICTs on individuals; the gap between computer literacy and those with and without internet access is increasing. 
$\checkmark \quad$ Impact on Social Interaction: Progress in information-communication technologies and network-based technological solutions have enabled the automation of most administrative functions and the use of information within online environment.

Various methods are used to evaluate the performance of the e-government. From these methods, the transaction costs use the grouping method to calculate the benefits for different groups of users and the service receivers. It is an easy and fast way to estimate cost savings for e-government applications. Net present value is an easy way to measure monetary values and concrete benefits. It is used when the benefits are measurable, where the cash flows are on an individual level. Cost-benefit analysis is a flexible method that measures tangible and abstract benefits and evaluates them according to net total costs. It ensures that the benefits are analyzed in a good way. But it can be expensive and time-consuming. Cost-effectiveness analysis focuses on achieving specific objectives related to marginal costs. It is taken into account marginal benefits for some specific purposes. Document analysis measures the total risk of expected savings on paperwork at an institutional level. Especially making a risk analysis is important in document analysis. Value estimates are used to monitor performance against general policy targets (Foley and Alfonso, 2009: 378).

\section{E-HEALTH PRACTICES IN TURKEY}

E-health is the use of all the functions of information and communication technologies to improve the health of citizens and patients and to increase access to health care services (T.C. Sağlık Bakanlığı, www.e-saglik.gov.tr, 24.12.2016). E-health applications bring many benefits to health care delivery. For example; health care costs are falling. Efficiency is provided in health service delivery and resource distribution. Communication between health personnel is increasing. Citizens who have difficulty accessing health services, such as living in rural areas or difficulties in transportation, may benefit from health services. Health personnel and citizens can access the information more easily. Thanks to new technologies, the relationshipbased approach has become more effective. The relationship-centered approach refers to a more sensitive approach to the needs of patients in accordance with doctors and patients' perspectives. It includes sharing treatment-related situations with patients and their relatives (Williams, et al., 2000: 80). In addition, today's patients have a more active role in the decisionmaking process to educate themselves about medical issues related to their illness before they come to see their doctors (Diaz, et al. 2002: 180). In this respect, e-health provides the improvement of the quality of the health services by taking the role of internet and similar technologies in the acquisition, transfer and development of the data related to the service. It requires the use of information and communication technologies for the development of local and general health services (Sivil Dayanışma Platformu, sdplatform.com, 22.12.2016). Thus, health services can be provided in the highest quality and fastest manner to big masses. E-health applications are a health presentation system based on knowledge and information systems. The system cares about human life. It seeks new methods in the treatment of diseases. It creates goals for the future. It provides quality service with stakeholders (IT Advisor, itadvisor.com.tr, 22.12.2016).

The basic aims of e-health projects are (T.C. Sağlık Bakanlığı, www.e.saglik.gov.tr, 24.12.2016): Establishment of data analysis support and decision support systems, acceleration of data flow among e-health stakeholders, to increase resource efficiency and productivity, to coordinate e-health initiative processes, to support scientific studies, adoption of e-health concept at national level.

There are five different stages of transition to the e-health system (Tan, 2005):

Level 1: At this stage patient records are still kept on paper in the patient services system. Some of the patient informations were transferred to the computer. Some of the procedures (such as patient registration, appointment, results, etc.) required by health services can be automated. Turkey is still first class.

Level 2: Patient records are digitalized and placed in the document monitoring system. The patient's information is scanned and transferred to the system as an optical image. However, the transfer of information to the system does not provide the opportunity to update and analyse user information to system's users.

Level 3: At this level, medical records serve as a decision-making support tool to user physicians. The records can alert service users.

Level 4: Electronic medical records keep only patient informations. Electronic patient service, as well as patient information records, include informations concerning all patient services and from other public institutions where the patient is connected. It is possible to see the information in the hospital where the patient applied in the past, which treatments were applied, and what kind of results the treatments gave. 
Level 5: At this level, information is obtained from a wider audience. The information that will give rise to general conclusions is detected. For example; informations about the eating habits of the individuals, the frequency of using cigarettes and alcohol are collected and reports are made according to the results. At this level, records are kept as welfare services records (Wager and et al., 2009).

The technologies used in health services and related units are evaluated in four categories (Omachonu, 1991: 10):

$\checkmark$ Technologies in the Field of Diagnosis: Diagnostic technologies are used for patient measurements and tests applied to the patient.

$\checkmark$ Technologies Used in Therapeutic Areas: They are used directly in the treatment of the patients.

$\checkmark$ Technologies Used in Information System Fields: It deals with providing, analyzing, storing and using information.

$\checkmark$ Multipurpose Technologies: Two or more technologies are represented together.

The main values of e-health concept in the articles published in Medical Internet Research are as follows (Eysenbach, 2001: 20):

1- Efficiency: One of the most important effects of e-health is to increase productivity by lowering wages. The way to reduce wages is to prevent duplicate and useless diagnoses and treatments by improving communication between health care providers and patients.

2- Care for Quality: E-health has the ability to compare health care institutions. Patients prefer organizations that offer better quality public services.

3- To Be Evidence-Based: The validity of e-health initiatives has been proven by intensive scientific researches.

4- Authorization: Patients have access to basic medical informations and personal electronic records via the internet with ehealth applications.

5- Encouragement: E-health transforms the health care into a form in which decisions are taken together, which treatment clearly describes.

6- Education: E-health supports the development of health professionals through online databases and consumers' through special preventive informations in health care.

7- Activation: E-health enables healthcare organizations to communicate with each other and exchange information in a common standard.

8- Expanding: E-health enables consumers to easily obtain health services from global service providers.

9- Ethics: E-health brings a new form to the interaction between patient and physician. Online professional practices introduce new problems in ethical issues such as information, privacy and equality.

10-Equality: Making health care more equitable for everyone is one of the main goals of e-health project.

Although health-related e-government practices began in 1991; it is known that integrated academic information systems created in the 1980s in healthcare in the US, one of the forerunners of e-government applications, are used. The ministry of health in Turkey has done a variety of studies for personnel movements, controlling of efficiency of the source, material and financial values over the internet. The document monitoring program was developed by the Ministry of Health Data Processing Center in order to be able to answer the documents in the provinces and to follow the results electronically via the internet and it started to be used in the intranet environment in the central organization of the ministry at the beginning of 2003 (Başbakanlık, 2002: 85). In May 2003, Turkey Health Information System Action Plan was prepared. The e-health studies in the Ministry of Health began in 2004 and were completed in January 2005. The necessary workings for e-health infrastructure in Turkey were made on 09.10.2016. In addition, since the year 2014, the Ministry of Health has set up health data warehouses covering across the country and plans to use the informatics applications through obtained the data from the center and the provinces over the Health Special Network (SB.net). In 2015, the Ministry of Health decided to transition to web-based architecture with applications such as Hospital Information Management Systems and Family Medicine Information Systems with the circular no. 2013/14 "Information and Communication Technologies". Established in 1996 and reorganized in 2011, the General Directorate of Health Information Systems has been brought to a contemporary structure.

Through the technological and administrative changes, the General Directorate of Health Information Systems developed new and effective strategies to implement the e-health transformation program (T.C. Sağlık Bakanlığı, 2013). Within the context of 
the Health Transformation Program and the scope of strategic management, the Ministry of Health has prepared the first strategic plan covering 2010-2014 years. Accordingly, the ministry is required to establish mobile health stations that will increase access to health services, to train educated health professionals in the EU standard to improve e-health management, and to support health information systems with facilities, equipment and technology.

In this section, the e-health projects conducted by the Ministry of Health are mentioned.

\subsection{Telemedicine}

Tele-medicine is the provision of communication technology and the use of information in health care services to the individuals who are away from health service providers. Thus, health workers exchange views with each other. They can share data. They use information systems and communication technologies to conduct health-related researches (Demirel, 2013: 73; Wallace, 1998: 777; Blackwell et al., 1997: 583). The beginnings of tele-medicine applications extend back to the 1960s. First, in 1964, a 180-kilometer closed-circuit television system was established between the Nebraska Institute of Psychiatry in Omaha and the State Mental Hospital in Norfolk. In our country, tele-medicine was first used in health services in the field of radiology and pathology. The project covers the state, education and research hospitals in various parts of Turkey (Işık and Güler, 2010: 2).

The aims of the Tele-Medicine project are (T.C. Sağlık Bakanlığı, www.e-saglik.gov.tr, 24.12.2016):

1- All images and informations about the patient are collected in the electronic area for digital and paperless hospital establishment.

2- To provide quality and certainity in patient evaluation, to reduce costs.

3- Knowledge and experience sharing among physicians.

4- Consultation in complex cases.

\subsection{Family Medicine Information System}

The Family Physician Information System communicates with the Ministry of Health Central Database via the internet and can send the data from the local base to the center. The system allows the communication between the physician and the Ministry of Health and the Provincial Public Health Directorate. With the Family Physician Information System, family physicians can record the health service offered by them in an electronic form. The data sets requested by the Ministry of Health from these recorded data are transmitted directly to the Ministry in the electronic environment (Ministry of Health, 2005: 6). First, this program started to be implemented in Düzce.

\subsection{Core Resource Management System}

The implementation of the Core Resource Management System began in 1997. The systems were established to record, monitor and plan all the resources of the country's health system. Buildings, tools and equipment, medical devices and materials, financial resources; buildings, facilities, services and human resources belonging to the private sector are recorded in the public health facilities with the system. With the Core Resource Management System, the Ministry of Health is able to follow up and plan the situation of all public personnel. It is a system used to manage, monitor and support resource planning of the Ministry of Health. The system consists of five modules: The Human Resources Management System module enables the monitoring of personnel movements, payroll and accrual procedures to be carried out in the Ministry of Health. With the basic health module, statistical follow-up of diseases and diseases that can be encountered in health institutions are recorded as data and evaluated as statistical data.

With the investment tracking system; The Ministry of Health's investments are being followed. The system includes information such as code, substitution and land registry informations, fire controls and earthquake analysis of all the buildings connected to the Ministry. The material resources management system records all the materials needed. The system is looking for the answer to the questions of which material is used, which institution and organization, and how much it is used. The management system of private health institutions monitors the establishment and personnel movements of private health institutions. It provides all kinds of information and document flows by including these institutions in the health private network (T.C. Sağlık Bakanlığı, www.saglik.gov.tr, 24.12.2016). 


\subsection{E-Prescription}

It is the regulation, correction, observation and transfer to the person or pharmacist of the pharmaceutical prescriptions using information and communication technologies. Under the e-prescription, the physicians transfer the prescription electronically to the pharmacists or persons in electronic environment (eHealth Initiative, 2010). It is possible to store the prescription electronically without the necessity of transferring the prescriptions to the paper environment. E-prescription minimizes human-induced mistakes. It constantly updates and improves the health system. It provides fast and repeatable service. It provides follow-up to the patient and controls unnecessary drug uses (T.C. Sağlık Bakanlığı, www.saglik.gov.tr, 22.12.2016). Considering that 1.5 million prescription papers are used daily in Turkey, it is understood that the system provides a great saving even in terms of paper savings (Demirel, 2013: 88).

\subsection{Drug Monitoring System}

Drug monitoring system is the adaptation of the follow-up and monitoring system that is applied all over the world to the pharmaceutical sector. Thanks to the electronic product code, it is a system to follow the drugs during the procurement and distribution. The most important purpose of the system is to ensure patient safety. Inputs and outputs are reported and stored in a database with the system since the production or import of drugs. Receiving a report on medicines is important both for ensuring drug safety and for detecting drug deceitfulness (T.C. Sağlık Bakanlığı, itsportal.saglik.gov.tr, 24.12.2016).

\subsection{Medula (General Health Insurance)}

It is aimed to record all the personnels and the health expenditures as the informatics arm of general health insurance. The general health insurance collects billing information electronically between health institutions. It is an integrated system designed to realize service payments (T.C. Çalışma ve Sosyal Güvenlik Bakanlığı, www.sgk.gov.tr, 24.12.2016).

With the Medula System, the disabilities of health services are prevented. The quality of the provided health services has increased. The health services are now available in a faster format. All information used in the health service is recorded in an electronic database with the Medula System. With the system, applications for monetary receivables of individuals and institutions have been resolved in a timely manner (SGK, 2013: 40).

\subsection{Central Hospital Appointment System}

The central hospital appointment system has made it easier for all citizens in the country to access health services within the scope of the health transformation program. It is a project developed for public hospitals to provide services more effective and efficient manner. With the project, it has been facilitated to apply health services from anywhere and all kinds of information communication tools. Citizens also can choose physicians according to their wishes. The project was first implemented in pilot regions of Erzurum and Kayseri in 2010. In 2011, this service was spread throughout the country (www.mhrs182.net, 24.12.2016).

\subsection{Health-NET}

Citizens with e-health portal called Health.NET can learn their own family physician and communicate with him. They also make appointments via the central hospital appointment system. They can see their health records. Health care personnels can also keep up-to-date informations and regulations about their area. They can report data through applications on the portal. They can access health reports and detailed statistics (Kırıcı, 2008). In this respect, Health.NET helps to identify problems and priorities and take measures in the health sector. The sector contributes to the planning of resources, workings and investments, and the assessment of the quality of health services. It collects and processes the data necessary for scientific researches and studies (T.C. Sağlık Bakanlığı, www.e-saglik.gov.tr, 24.12.2016). Health-NET has brought quality and standard to health services. With Health-NET, only the data collected in statistical and printed form have been collected to cover all the health information from the birth to the death of the patient. Electronic health records of citizens have been shared among different health institutions (Yıldız, Ertuna and Uçar, 2009: 108).

\subsection{Decision Support System}

The decision support system ensures that data in the decision-making process are collected, stored, analyzed and easily accessed. The data obtained are used in the planning of health services, in determining the strategies and in making critical management decisions. The Ministry of Health aims through the system to report the data in applications such as e-health, core resource management system to every level user over decision support system-geographical information system platform. In 
this regard, the decision support system aims to support to the users in decision making process. Thus, the system helps to solve semi-structural and non-structural problems (Demirel, 2013: 71).

\subsection{One-Order Accounting System}

It has been determined that financial and fiscal statements of healthcare providers are different in accounting, business and the Ministry of Health. In this respect, it is necessary to tabulate the financial and fiscal tables in the accountings in a uniform and appropriate standard. For this, it is aimed to process the accounting records and informations with standard software in oneorder accounting system (T.C. Sağlık Bakanlığı, www.tdms.saglik.gov.tr, 24.12.2016).

\subsection{Ministry of Health Communication Center}

Ministry of Health Communication Center has been active in 1.1.2004. The aim of the center is to make interactive management effective with the participation of ministry personnels and citizens. The center contributes to the resolution of problems arising from lack of communication between the public and the administrators. It serves citizens for seven days and 24 hours by phone number 184. Each Provincial Director of Health and the assistants of the director were appointed as the Ministry of Health communication center authority (T.C. Sağlık Bakanlığı, sabim.saglik.gov.tr, 24.12.2016).

\subsection{Electronic Transfer System}

With the implementation of the central hospital appointment system, it became possible for patients to make appointments to a different hospital over the Health.NET infrastructure. In this context, the information of patients who have made an appointment from a different hospital with electronic transfer system is sent in an electronic environment and transfer of the patient is carried out (T.C. Sağlık Bakanlığı, www.e-saglik.gov.tr, 24.12.2016).

\subsection{National Health Data Dictionary}

It is a dictionary work that is referenced by the hospital information systems used by the health institutions in Turkey. The dictionary contains hierarchical inter-term relations that are of different data sets. The data dictionary simply provides for the collection, analysis and evaluation of data from health institutions in accordance with established standards. The first version of the National Health Data Dictionary was created in 2007 by the Ministry of Health Data Processing Department (T.C. Sağlık Bakanlığı, www.e-saglik.gov.tr/TR7141/usvs.html, 24.12.2016).

\subsection{E-Pulse}

It is a personal health record system where all health information is managed and can be accessed from one location to the medical background. Detailed information on all examinations and treatments can be obtained with e-pulse. The examinations are evaluated in terms of service quality. You can comment on the health services you received. All laboratory test results and radiological views are recorded on e-pulse. In the e-pulse application, all data is encrypted and stored. The project has been in operation since 1 March 2015. The system has been used by all family physicians and other health care providers through a common channel. The project provides access to all health informations and documents from everywhere in the most economical way (T.C. Sağlık Bakanlığı, enabiz.gov.tr/Yardim.html/\#url13, 24.12.2016).

\subsection{The Pension Fund and SSK E-Health Applications}

With the supervision project of the pension fund's health expenditures, while pharmacies act on prescription process, they connect to the computer center of the pension fund and perform the data entry from their computers. Thus, it is evident whether the person has the right to benefit from the health service, whether the medicines entered into the system will be paid, or how much will be paid. In addition, patient participation payments and the amount that the pension fund will pay to the pharmacy are reflected on the pharmacy's computer. The tests and treatments made by the health centers are evaluated according to the coding system and the budget implementation order prices and they are taken into computer records on a person basis. Under the Social Insurance Institution (SSK), the infrastructure of the central and provincial insurance units has been renovated and a e-insurance project has been passed down for follow-up of the institution's revenues and expenditures. With the e-insurance project, all the employer informations, accrual and collection accounts in the province can be monitored from the center in Ankara. The affiliated institutions of the Ministry of Health require provision for the SSK members who apply to them. During the provisioning process, it is checked whether the SSK member has the right to receive health services or not. It is called "entitlement" for an SSK insured or a pensioner to qualify for health care. The rights acquisition control web service does this procedure. (Güleş ve Özata, 2005: 159-163). 


\section{CONCLUSION}

The importance of social change in the development of the states is great. The social change process has started with the transition to the agricultural society and continued with the industrial society where production and consumption are important. The transition to information society, which is perceived as the last wave, and information and information technologies have started to be used almost everywhere from education to health. The most important element in the information society is the widespread use of produced knowledge. The prevalence of information increases organizational effectiveness in terms of operational processes. For this purpose, steps such as the collection, storage, processing, display and control of information are important for the development of information technologies. In the public sector, e-government emphasizes the importance of concepts such as speed, time and quality, and argues that information technology produces new solutions for administrative reforms. According to this; in public administration, e-government will reduce costs together with on-line presentation of public services and will prevent bureaucratization. It will provide administrative transparency and accountability by increasing citizen participation in administrative and political processes. It is expected that e-government applications will be useful in services based on information, communication, participation, data transfer services and transactions. With the use of e-government applications in the health sector, all detailed information about patients can be kept within a system. Physicians can access all the information about the patients instantly and make more accurate diagnoses. Technological applications in health services are aimed at reducing costs in the health sector, facilitating operations, creating a competitive environment and providing quality. The internet is one of the most common applications in researching health related informations. Patients can easily access medications, treatments and new applications in the healthcare sector from the internet. It has become possible with information and communication technologies that health information can be accessed from the desired place and at any time. With the use of electronic data entry systems, electronic applications have gained widespread use in the health sector. This situation ensures time and labor costs savings. The correctness of the data, transfer speed, wide accessibility, and interconnection of data elements improve performance on a technical system basis. The records stored in the long term in the electronic environment are important for medical researches, comparative statistics on health, quality studies and national strategic planning goals. E-health applications are expected to increase effectiveness in health care services. These practices give the patient more responsibility. Individuals decide more conscious about own health conditions. In addition, it increases the interaction between the patient and the healthcare provider in health care. Thus, healthcare services are delivered by reducing the number of medical errors and making clinical processes more efficient in accordance with the requirements of the information society.

Although Turkey is in the first stage of transition to the e-health system; Turkey has achieved an important milestone in the last decade, along with a health transformation program. The Ministry of Health, which has carried out many successful projects in the field of e-health, has increased the effects of technological development on health sector by supporting its health policies with information technologies. It has become possible to exchange views between health personnel with tele-medicine. The family medicine information system allows family physicians to record patient informations and, if necessary, transfer these informations to the Ministry of Health.

The core resource management system allows the Ministry of Health to manage, monitor and plan for its own resources. Eprescription practices have reduced red tape and unnecessary bureaucratic processes. The drug monitoring system records the inputs and outputs of drugs. It secures drug safety. The Medula system is provided to store informations from health services in an electronic database.

The central hospital appointment system made it easier for citizens to apply for health services. The Health.NET portal provides quality control of health services and standardization of services offered. The decision support system adopted a user-focused approach and made the decision-making process easier.

The one-order accounting system ensures that accounting entries are recorded in a standardized order, avoiding the fragmentation in financial records in the health field. The electronic transfer system has carried out the transfer of patients from one hospital to another without the need for bureaucratic procedures. The national health data dictionary is an essential resource for hospital information systems. The e-pulse project allows patients to receive detailed information about their examinations and treatments. The pension fund and SSK's e-health applications control health spendings and automatically identify those who qualify for health care. As you can see; The Ministry of Health has demonstrated the importance of information technology in health policies by introducing multi-directional projects in e-transformation process. The widespread use of e-health applications by citizens consciously will further enhance the impacts and successes of information technologies on the health policies. 


\section{REFEFERENCES}

Affisco, John F. and Khalid S. Soliman, 2006, "E-government: A Strategic Operations Management Framework for Service Delivery", Business Process Management Journal, Vol.12, Iss.1, pp-13-21.

Asgarkhani, Mehdi, 2005, "Digital Government and its effectiveness in Public Management Reform: A Local Government Perspective", Vol.7, I. 3, pp.465-487.

Başbakanlık, 2002, E-Türkiye Girişimi Eylem Planı, Ankara.

Blackwell Nikki A. M., Graeme J. Kelly and Lee M. Lenton, 1997, "Telemedicine Ophthalmology Consultation in Remote Queensland", The Medical Journal of Australia, 167 (11-12), pp.583-586.

Demirel, Ahmet, 2013, Sağlık Hizmetleri Yönetiminde Sağlık Bilgi Sistemleri ve Kullanım Modülleri, Beykent Üniversitesi Sosyal Bilimler Enstitüsü Yayınlanmamış Yüksek Lisans Tezi, İstanbul.

Diaz, Joseph A., Griffith Rebecca A. et. al, 2002, Patient's Use of Internet for Medical Information, Journal Gen Intern Medicine, 17 (3), pp.180-185.

eHealth Initiative, 2010, The Basics: What is Electronic Prescribing?, http:// www.ehealthinitiative.org/basics-what-electronicpreseribing.html, (27.12.2016).

Eysenbach, G., 2001, “What is e-Health?” Journal Medical Internet Research, 3 (2): e20.

Foley, Paul and Ximena Alfonso, 2009, "eGovernment and the Transformation Agenda", Public Administration, Vol.87, No.2, pp.371-396.

Güleş Hasan Kürşat ve Musa Özata, 2005, Sağlık Bilişim Sistemleri, Nobel Yayınevi, Ankara.

Gates, Bill ve Hamingway C., 1999, Dijital Sinir Sistemiyle Düşünce Hızında Çalışmak, (Çev. Ali Cevat Akkoyunlu), Doğan Kitapçılık, İstanbul.

Homburg M. F. Vincent, 2008, "Red Tape and Reforms: Trajectories of Technological and Managerial Reforms in Public Administration", 31:7, pp.749-770.

İzci, F., 2001, Bilişim Teknolojilerinin Kamu Örgütleri Üzerindeki Etkileri ve Sağlık Bakanlığı Örneği, Cumhuriyet Üniversitesi Sosyal Bilimler Enstitüsü, Yayınlanmamış Doktora Tezi, Sivas.

IT Advisor, http://itadvisor.com.tr/e-saglik-hizmetleri-hizla/gelisiyor, (22.12.2016).

Işık, A. H., Güler I.., 2010, "Teletıpta Mobil Uygulama Çalışması ve Mobil illetişim Teknolojilerinin Analizi”, Bilişim Teknoloji Dergisi, 3 (1), ss.1-10.

Kırıcı, S., 2008, “Sağlık-NET Portalı ve Karar Destek Sistemi”, www.sagliknet.saglik.gov.tr/giris.htm, (27.12.2016).

Moon, Jae M., Jooho Lee, Chul-Young Roh, 2014, "The Evolution of Internal IT Applications and e-Government Studies in Public Administration, Research Themes and Methods" Administration\&Society, Vol.46 (1), pp.3-36.

Omachonu, Vincen, K., 1991, Total Quality and Productivity Management in Health Care Organizations, Georgia Industrial Engineering and Management Press.

SGK, 2013, Genel Sağlık Sigortası Medula Web Servisleri Kullanım Kılavuzu, Ankara.

Sivil Dayanışma Platformu, sdp.platform.com/Dergi/138/Saglik-bilisimi-ile-SGK-saglikta-tek-aktor-olmaya-dogru-ilerliyor.aspx, (22.12.2016).

Tan, Joseph, 2005, E-Health Care Information Systems: An Introduction for Students and Professionals, Jossey-Bass, USA.

T.C. Çalışma ve Sosyal Güvenlik Bakanlığı, Sosyal Güvenlik Kurumu, www.sgk.gov.tr/wps/wcm/connect/6bcc4d2870314d04963ea500ad6a0ea/MedulaSistemi.ppt?MOD=AJPERES, (26.12.2016).

T.C. Sağlık Bakanlığı, 2005, Aile Hekimliği Uygulamasına Başlarken Yapılması Gereken Hazırlıklar, Ankara. 
T.C. Sağlık Bakanlığı, 2013, Sağıık Bilgi Sistemleri Genel Müdürlüğü 2013/14 Sayılı Genelge, Ankara.

T.C. Sağlık Bakanlığı, www.e-saglik.gov.tr/ERadyoloji.aspx; www.saglik.gov.tr/SBWEBUYGULAMA/belge/1-17502/ckys.html, (24.12.2016).

T.C. Sağlık Bakanlığı, www.saglik.net.saglik.gov.tr, (22.12.2016).

T.C. Sağlık Bakanlığı, its.portal.saglik.gov.tr/index.php?run=content\&get=14\&mp=3,10, (24.12.2016).

T.C. Sağıı Bakanlığı, www.e-saglik.gov.tr/belge/1-33811/sagliknet-hakkında.html; www.tdms.saglik.gov.tr; sabim.saglik.gov.tr; enabiz.gov.tr/Yardim.html/\#url13, (24.12.2016).

T.C. Sağıı Bakanlığı, www.e-saglik.gov.tr/TR,7141/usvs.html, (24.12.2016).

Wager, K., Lee, F., Glaser, J., 2009, Health Care Information Systems: A Practical Approach for Health Care Management, 2nd Edition, Jossey-Bass, USA.

Williams C. Geoffrey, Frankel M. Richard, Camphell L. Thomas and Deci L. Edward, 2000, "Research on Relationship Centered Care and Health Care Outcomes from the Rochester Bio psychosocial Program: A Self-Determination Theory Integration", Families, Systems\&Health, Vol.18, No.1, pp.79-90.

Wallace, Gordon, 2001, "Information Technology and Telemedicine", CMAJ: Canadian Medical Association Journal, 165 (6), pp.777-779.

www.mhrs182.net, (24.12.2016).

Yıldız İ., Ertuna E., Uçar E., 2009, "Sağlık-NET ve Harran Üniversitesi Uygulamaları”, 9. Akademik Bilişim Konferansı Bildirileri, Şanlıurfa, ss.107-110. 